\title{
Latest Permian to Middle Triassic cyclo-magnetostratigraphy from the Central European Basin, Germany: Implications for the geomagnetic polarity timescale
}

\author{
Michael Szurlies* \\ GeoForschungsZentrum Potsdam, Telegrafenberg Haus C, D-14473 Potsdam, Germany \\ Received 7 May 2007; received in revised form 10 July 2007; accepted 13 July 2007 \\ Available online 20 July 2007 \\ Editor: R.D. van der Hilst
}

\begin{abstract}
In Central Germany, the about $1 \mathrm{~km}$ thick mainly clastic Germanic Lower Triassic (Buntsandstein) consists of about 60 sedimentary cycles, which are considered to reflect variability in precipitation within the epicontinental Central European Basin, most probably due to solar-induced short eccentricity cycles. They provide a high-resolution cyclostratigraphic framework that constitutes the base for creating a composite geomagnetic polarity record, in which this paper presents a Middle Buntsandstein to lowermost Muschelkalk magnetostratigraphy obtained from 6 outcrops and 2 wells where a total of 471 samples was collected. Combined with recently established records, a well-documented magnetostratigraphy for the upper Zechstein to lowermost Muschelkalk (latest Permian to Middle Triassic) of Central Germany has been constructed, encompassing an overall stratigraphic thickness of about $1.3 \mathrm{~km}$ and 22 magnetozones derived from about 2050 paleomagnetic samples. Along with available biostratigraphy, this multi-disciplinary study facilitates detailed links to the marine realm, in order to directly refer biostratigraphically calibrated Triassic stage boundaries as well as radioisotopic ages to the Buntsandstein cyclostratigraphy and, conversely, to contribute to calibrating the geologic timescale.
\end{abstract}

(C) 2007 Elsevier B.V. All rights reserved.

Keywords: magnetostratigraphy; cyclostratigraphy; Buntsandstein; Permian; Triassic; Central European Basin; Germany

\section{Introduction}

The transition from the Paleozoic to the Mesozoic is indicated by the most severe mass extinction of the entire Phanerozoic (Erwin, 1993) affecting both marine and terrestrial biota (e.g. Erwin, 1993; Retallack, 1995). A precise chronology and a detailed stratigraphic correlation of strata from different depositional environments are central to understanding the nature and tempo

\footnotetext{
* Tel.: +49 331288 1362; fax: +49 3312881302

E-mail address: szur@gfz-potsdam.de.
}

of this end-Permian ecosystem collapse as well as the timing of the subsequent biotic recovery that has long been recognized as the longest recovery interval of the Phanerozoic spanning most of the Early Triassic (e.g. Erwin, 1993). However, the duration of the Early Triassic has been poorly constrained, until radioisotopic ages for the Lower-Middle Triassic boundary interval recently provided reliable tie points for the Triassic recovery (Ovtcharova et al., 2006; Lehrmann et al., 2006).

Using mainly lithological criteria, the Triassic geological system was originally introduced by von Alberti (1834), in order to unite the predominantly continental 
Buntsandstein, the marine Muschelkalk, and the mainly continental Keuper from the epicontinental Central European Basin (CEB). However, the term Triassic is used today in a chronostratigraphic sense with the formal definition of stages and substages being tied to marine strata from the Tethyan and Boreal realms and defined by their fossil succession, above all conodonts and ammonoids (e.g. Gradstein et al., 2004). A sole biostratigraphic comparison of the Germanic Triassic with the marine scale is in parts equivocal or impossible, e.g. due to fossil-free intervals (e.g. Kozur, 1999; Bachmann and Kozur, 2004). Accordingly, a more detailed and more reliable global correlation of the Buntsandstein requires the integration of other methods, such as magnetostratigraphy.

The global synchronous character of magnetic polarity reversals has made magnetostratigraphy a powerful tool for precise facies-independent correlation between different depositional environments. In the last two decades, significant progress has been made in constructing an integrated biomagnetostratigraphy for the marine Lower Triassic and, particularly, the Permian-Triassic boundary (PTB) interval (e.g. Heller et al., 1988; Li and Wang, 1989; Ogg and Steiner, 1991; Muttoni et al., 1996; Scholger et al., 2000; Gallet et al., 2000; Tong et al., 2004). With the objective to enable also detailed global correlation of the Germanic Triassic, a considerable number of studies focused on Buntsandstein magnetostratigraphy (e.g. Nawrocki, 1997; Soffel and Wippern, 1998; Nawrocki and Szulc, 2000; Hounslow and McIntosh, 2003; Szurlies et al., 2003; Szurlies, 2004), in which this paper presents a Middle Buntsandstein to Lower Muschelkalk geomagnetic polarity record for Central Germany derived from 6 outcrops and 2 continuously cored wells (Fig. 1). It represents the continuation of a comprehensive Buntsandstein study (Szurlies, 2001; Szurlies et al., 2003; Szurlies, 2004), now combined to a magnetostratigraphy for the upper Zechstein to Lower Muschelkalk (Late Changhsingian to Early Anisian) that is tied to an integrated (gammaray) log- and cyclostratigraphy. Along with available biostratigraphy, this multi-disciplinary approach aims to facilitating detailed links to the marine Triassic, in order to directly refer radioisotopic ages to the Buntsandstein cyclostratigraphy, and hereby, to test its relationship to the Milankovitch frequency band. Conversely, this cyclostratigraphy can be used to contribute to calibrating the Early Triassic stages and substages.

\section{Geological setting and Buntsandstein stratigraphy}

In the CEB (Fig. 1), the transition from the mainly continental Permian (Rotliegend and Zechstein groups) to the epicontinental tripartite Germanic Triassic (Buntsandstein, Muschelkalk, and Keuper groups), i.e. the uppermost Zechstein to Lower Buntsandstein, is developed mainly in red bed facies, in which this interval is assumed to represent one of the most complete sedimentary successions across the PTB world-wide (Menning et al., 2005). In Central Germany, the uppermost Zechstein is indicated by hypersaline and sabkha sediments overlain by the about $1 \mathrm{~km}$ thick mainly clastic Buntsandstein deposited in predominantly fluvio-lacustrine environments with the fluvial influx mainly originating from the massifs at the southern margin of the CEB (Fig. 1). Marine influences are restricted to parts of the Middle and, particularly, the Upper Buntsandstein, in which the clastics and carbonates of the latter gradually pass upwards into the marine Muschelkalk limestones.

Traditionally, the subdivision of the Buntsandstein relies on lithological criteria (von Alberti, 1834). Using a combination of geological mapping and wireline logs (e.g. gamma-ray logs), the first modern Buntsandstein lithostratigraphy was introduced by Boigk (1959), today consisting of (a) a twofold Lower Buntsandstein (Calvörde and Bernburg formations), (b) a fourfold Middle Buntsandstein (Volpriehausen, Detfurth, Hardegsen and Solling formations), and (c) the Upper Buntsandstein (Röt Formation). Moreover, the Buntsandstein is indicated by a striking cyclicity of varying magnitude, pragmatically subdivided into 10 to $30 \mathrm{~m}$ thick small-scale fining-upward cycles (e.g. Paul and Klarr, 1988; Geluk and Röhling, 1997; Szurlies, 2001; Roman, 2004), which, in turn, consist of 3 to 6 cycles of higher order (Szurlies, 2001). Commonly, these cycles begin with fluvial sandstones that grade into pelitic sediments, which were deposited in playas or playa lakes, respectively (e.g. Paul and Klarr, 1988). Alternatively, the sedimentary pattern can be interpreted as consisting of almost symmetric baselevel cycles (Szurlies, 2001, 2005), which are considered to reflect variability in precipitation (so-called wet-dry cycles) within the lacustrine system of the CEB most likely due to solar-induced short eccentricity cycles (e.g. Geluk and Röhling, 1997; Szurlies, 2001; Szurlies, 2005). For the interior of the CEB, the hitherto postulated synchronous character of these cycles has recently been proven by magnetostratigraphic means (Szurlies et al., 2003; Szurlies, 2004).

The sedimentary cycles can be used for correlation in cores, outcrops and wireline logs, for instance gammaray logs (GR logs), which in the Buntsandstein strata basically display the content of ${ }^{40} \mathrm{~K}$ that, above all, is present in clay minerals. Accordingly, the GR logs roughly reflect the clay content ("shaliness") with the lower mainly sandy part of a cycle being indicated by 


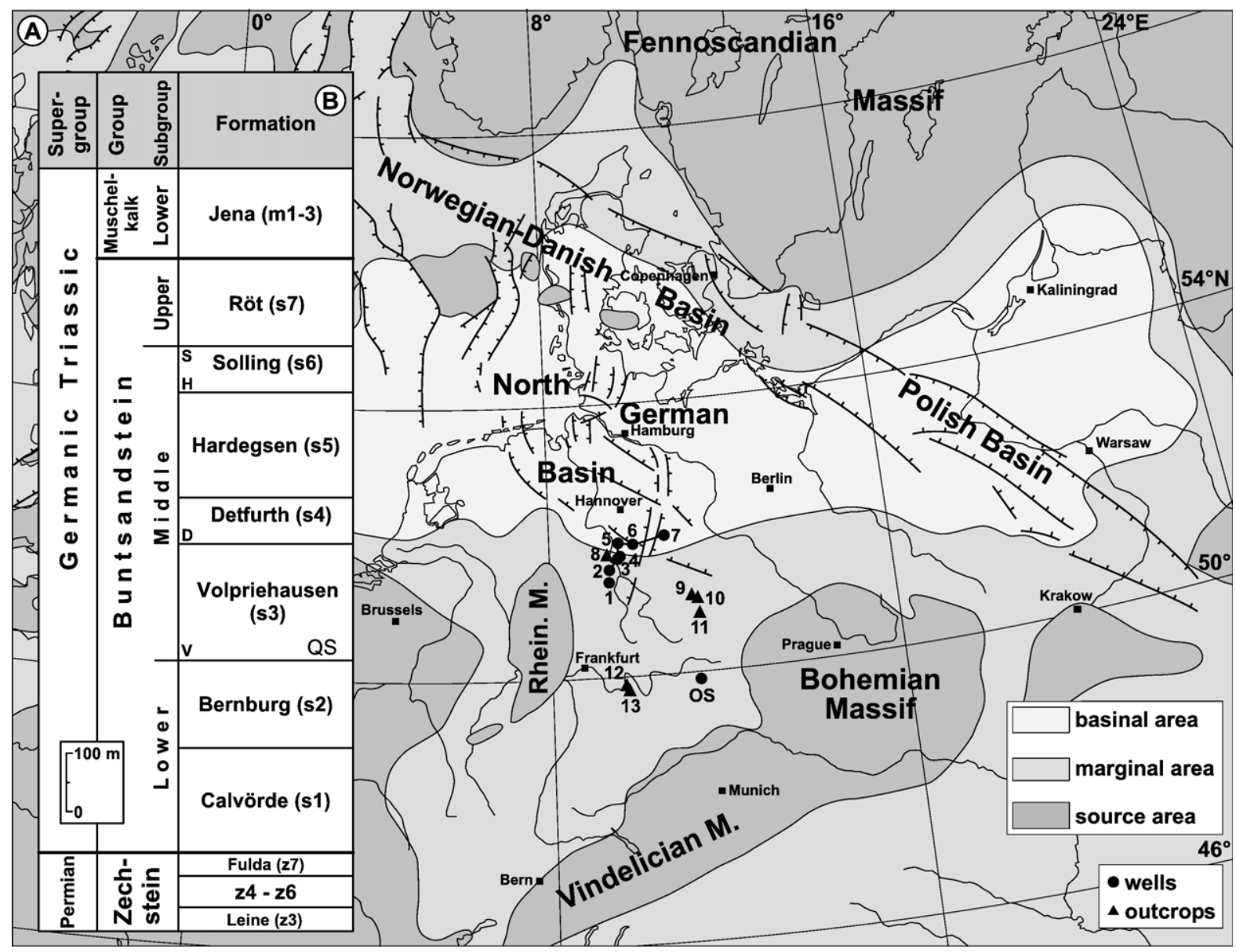

Fig. 1. (a) Paleogeographical map of the Buntsandstein from the Central European Basin (from Röhling et al., 2002) with location of outcrops and wells used in this study. Wells: $1=$ Dokumenta 6/77, $2=$ Beberbeck 1 (BB), $3=$ Solling 5, $4=$ Dassel VB2, $5=$ Brüggen Z1, $6=$ Bockenem A100 (BA), 7 = Königslutter Z1, OS = Obernsees; Outcrops: 8 = Bad Karlshafen (BK), $9=$ Karsdorf (KD), $10=$ Fliegerrutsche (FL), $11=$ Steudnitz (ST), 12 = Klingelbachtal (KT), 13 = Wüstenzell (WZ). (b) Lithostratigraphy of the upper Zechstein to Lower Muschelkalk in Central Germany. $\mathrm{V}-\mathrm{S}=$ Buntsandstein unconformities; QS = Quickborn Sandstone, which is regarded as the lowermost member of the Volpriehausen Formation (Bachmann and Kozur, 2004; Menning et al., 2005).

low GR values, whereas the subsequent dominantly pelitic interval is characterized by significantly higher radioactivities (Fig. 2; see also Szurlies et al., 2003; Szurlies, 2004 and references therein). Hence, field gamma-ray measurements enable to compare directly outcrop geology with geophysical borehole logs (e.g. Szurlies, 2004). Using regional GR log transects, the cycles can be mapped over large parts of the CEB (e.g. Geluk and Röhling, 1997; Szurlies, 2001; Roman, 2004; Geluk, 2005). Additionally, correlation is supported by numerous well-known litho and GR markers, e.g. the coarse-grained sandstone intervals at the base of the Volpriehausen and Detfurth formations (VS, DS), which are displayed as intervals of distinctive low radiation (Fig. 2). Based on a comprehensive (GR) log- and lithostratigraphic analysis, a subdivision into about 60 sedimentary cycles has recently been established (Szurlies, 2005), providing a high-resolution cyclostratigraphic framework of the Buntsandstein that forms the base for a reasonable composite magnetic polarity record (e.g. Szurlies et al., 2003; Szurlies, 2004). This is of outstanding importance, since the Middle Buntsandstein is indicated by four well-known unconformities, which either become obvious on swells or even have a regional to basin-wide extend like the prominent Hardegsen unconformity ( $\mathrm{H}$ unconformity) at the base of the Solling Formation (Fig. 1 and 2).

During the Late Cretaceous, the Mesozoic sedimentary succession of the CEB was affected by block-faulting and local thrust faults, due to intraplate compressional stresses, which were exerted on the European craton in the early phases of the Alpine plate collision. 


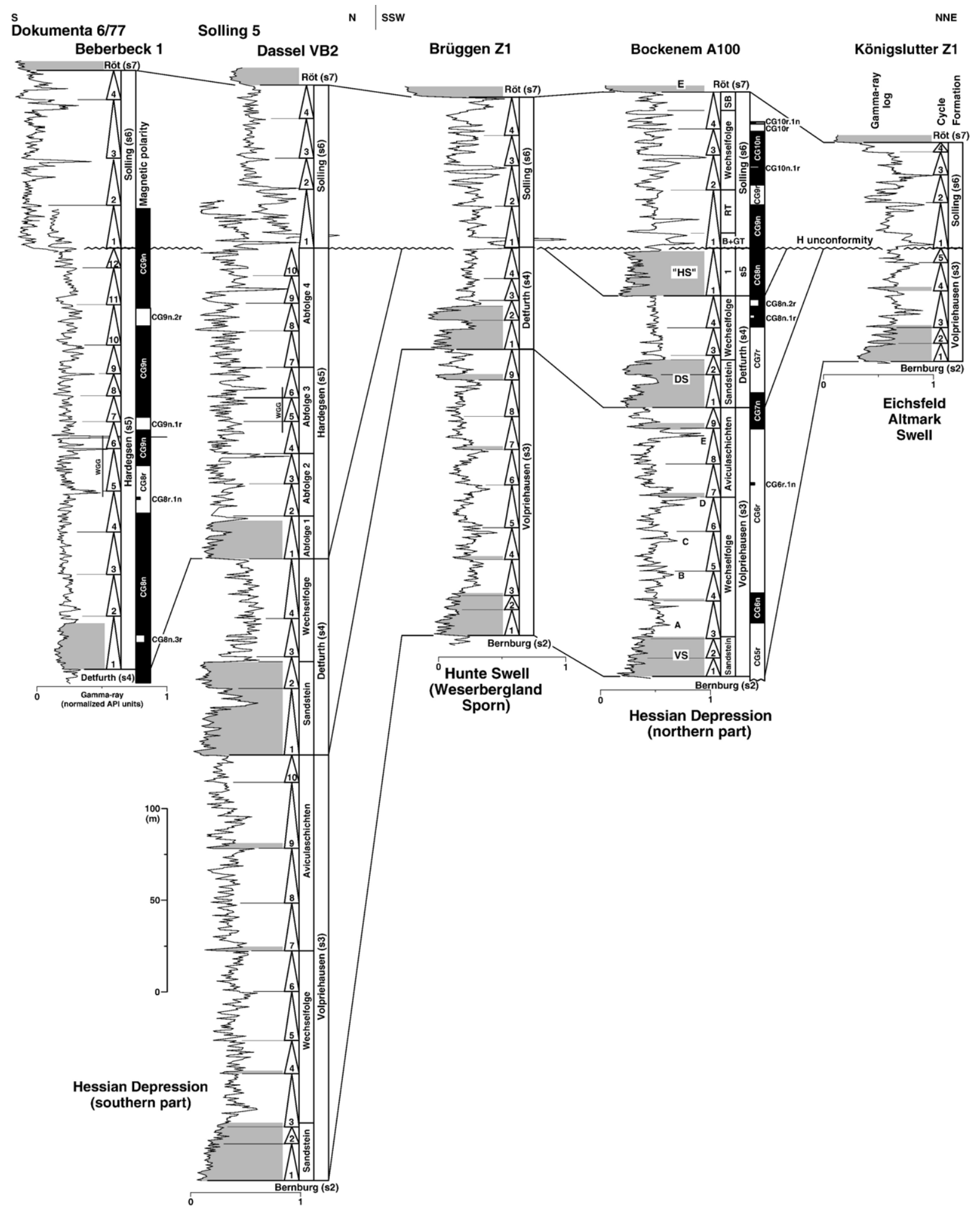

Fig. 2. Gamma-ray log correlation of the Middle Buntsandstein in an approx. NNE-SSW transect crossing the paleogeographical elements Hunte Swell, Hessian Depression and Eichsfeld-Altmark Swell. A-E = high-radiation markers; VS = Volpriehausen Sandstone, DS = Detfurth Sandstone, "HS" = "Hardegsen Sandstone", B +GT = basal sandstone + gray claystone interval, RT = red claystone interval, SB = equivalent of the Stammen Beds, $\mathrm{WGG}=$ white-gray-colored interval. See Fig. 1 for key. 


\section{Magnetic properties}

\subsection{Materials and methods}

In all, 471 oriented paleomagnetic standard samples were collected from the Buntsandstein and Muschelkalk sections with an average spacing of about $3 \mathrm{~m}$ using a portable water-cooled rock drill. The Middle Buntsandstein was examined in two continuously cored wells and one outcrop (Fig. 1) yielding a total of 319 specimens. From the overlying Upper Buntsandstein to lowermost Muschelkalk, 152 samples were recovered in five outcrops. Preferentially, fine-grained sandstones, siltstones and claystones (mainly red-brown lithologies) were collected. Additionally, limestones were sampled in the uppermost Buntsandstein and Muschelkalk (exclusively gray lithologies).

Thermal treatment of the red-brown samples was performed using an ASC Scientific TD48 oven with measurements of natural remanent magnetization
(NRM) being made with a $2 \mathrm{G}$ Enterprises automatic DC-SQUID 755SRM cryogenic magnetometer (noise level $\left.1 \times 10^{-6} \mathrm{~A} / \mathrm{m}\right)$. Routinely, the magnetic susceptibility was recorded after each demagnetization step with a Bartington MS2B sensor in order to monitor mineralogical alteration of the magnetic fraction due to heating. Demagnetization of the gray lithologies was performed using the in-line triaxial alternating field demagnetizer of the cryogenic magnetometer.

Isothermal remanent magnetizations (IRM) were applied with a $2 \mathrm{G}$ Enterprises 660 pulse magnetizer and measured with a Molyneux MiniSpin fluxgate magnetometer (noise level $0.2 \times 10^{-3} \mathrm{~A} / \mathrm{m}$ ). Samples were exposed stepwise, to peak fields of 10 to $2700 \mathrm{mT}$ along the positive $z$-axis of the specimens in order to record complete IRM acquisition curves. For a more conclusive interpretation, IRM experiments were combined with subsequent thermal demagnetization of IRM, since magnetic minerals exhibiting similar coercivities, generally, are characterized by different unblocking temperatures.
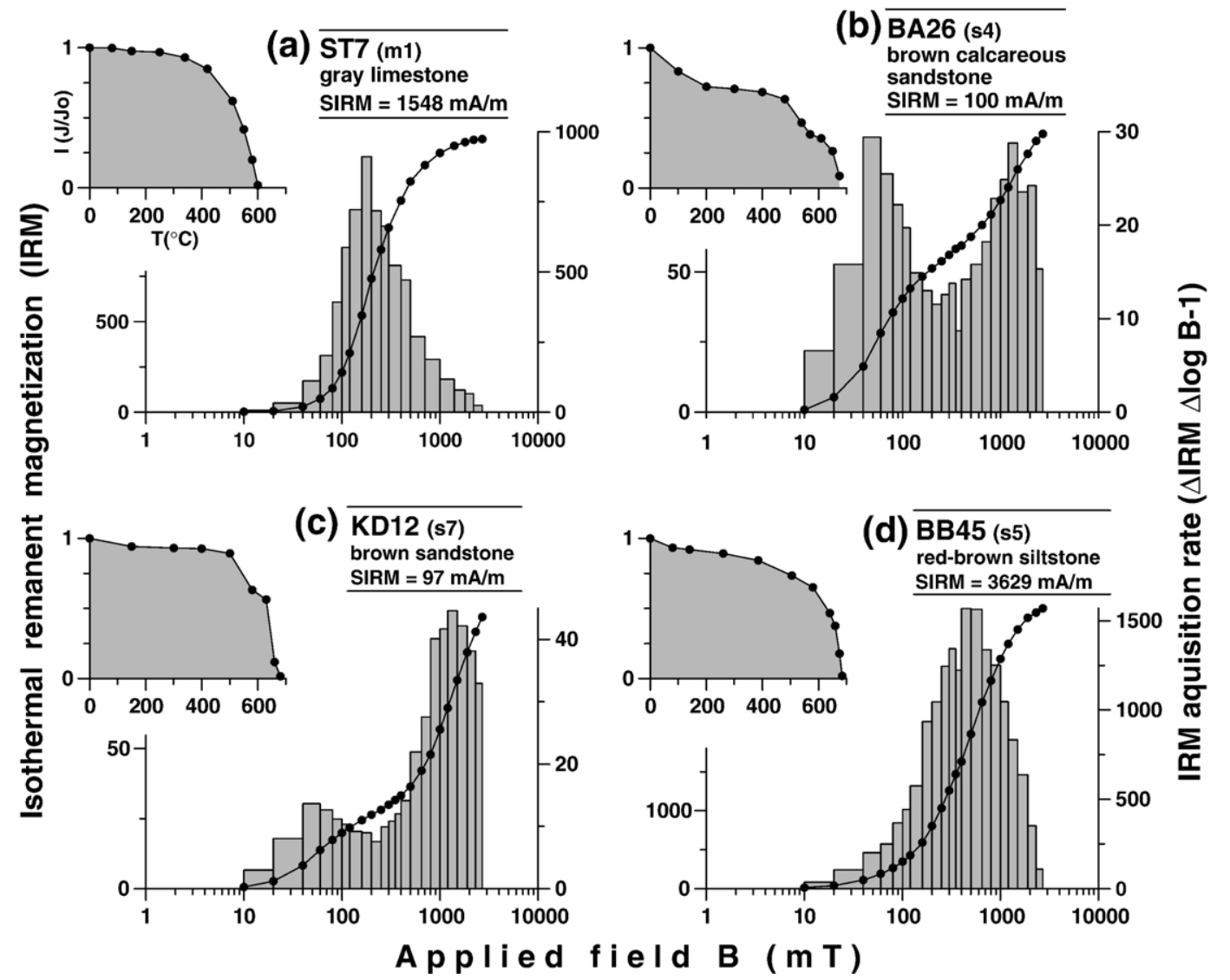

Fig. 3. (a-d) IRM acquisition curves in fields up to $2700 \mathrm{mT}$ and subsequent stepwise thermal demagnetization of IRM for four representative lithofacies types with samples being identified by abbreviation of section name and chronological sampling number. See Fig. 1 for key. 


\subsection{Rock magnetism}

Routinely, a representative suite of specimens was selected for IRM experiments (Fig. 3) where the behavior of the gray and red-brown lithologies revealed significant differences. Usually, the gray samples are dominated by a low coercivity fraction, acquiring the majority of IRM between 50 and $200 \mathrm{mT}$ (Fig. 3a) and having a corresponding maximum unblocking temperature of about $590{ }^{\circ} \mathrm{C}$, which is ascribed to magnetite. Commonly, most of IRM is reached in ambient fields of less than $500 \mathrm{mT}$.

The red-brown lithologies reflect the presence of a high coercivity mineral (Fig. 3b-d). It is saturated between 600 and $\sim 2000 \mathrm{mT}$ revealing an accompanying maximum unblocking temperature of $680^{\circ} \mathrm{C}$, which is attributed to hematite. Additionally, in some gray and brown samples an inflection in the acquisition curves is displayed at about $200 \mathrm{mT}$ indicating the presence of a low coercivity fraction (Fig. 3b-c). It acquires most of the IRM in fields of less than $150 \mathrm{mT}$ exhibiting a noticeable drop in the demagnetization curves between 500 and $600{ }^{\circ} \mathrm{C}$, identified as most probably magnetite. Most of the red-brown lithologies as well as some gray samples are not entirely saturated at maximum field of $2700 \mathrm{mT}$ (Fig. 3b-d), often also revealing a significant drop in the corresponding thermal demagnetization curves at about $100{ }^{\circ} \mathrm{C}$, which obviously indicates the presence of goethite.

\subsection{Paleomagnetic properties}

The intensity of the NRM is on average $2.31 \mathrm{~mA} / \mathrm{m}$, ranging from 0.04 to $14.56 \mathrm{~mA} / \mathrm{m}$. Continuing a recently established nomenclature (Szurlies et al., 2003; Szurlies, 2004), the behavior of the samples during demagnetization was divided into two classes, i.e. type I and II magnetizations.

Usually, the NRM of the red-brown and gray samples consists of at least two superimposed magnetization directions (components $\mathrm{A}$ and $\mathrm{B}$ ) related to lower and

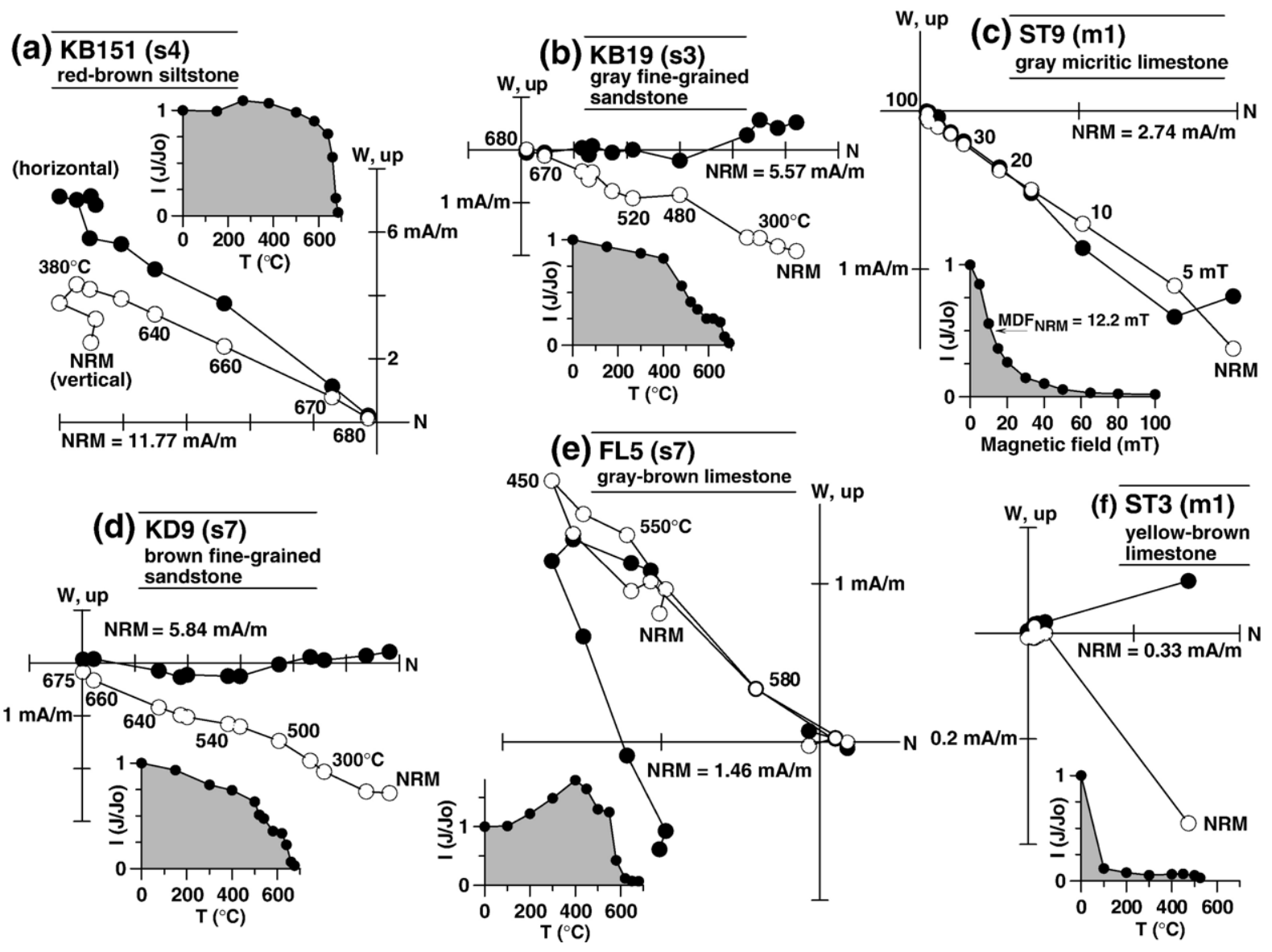

Fig. 4. (a-f) Vector end-point diagrams and normalized intensity decay curves illustrateng thermal and alternating field demagnetization of NRM for six representative samples with the demagnetization results assigned to type I (a-e) and type II (f) magnetizations, respectively. See Fig. 1 for key. 


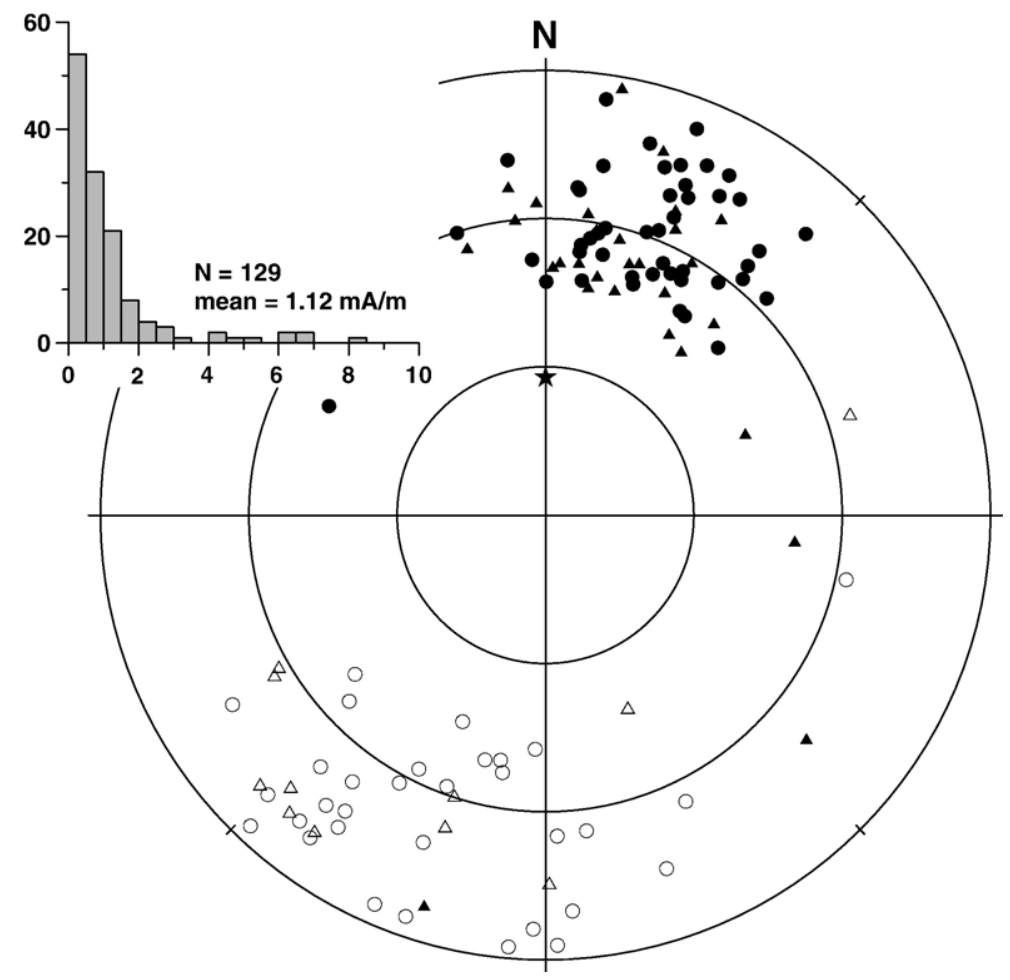

Fig. 5. Stereographic projection of the ChRM directions, i.e. type I magnetizations, from all 6 studied outcrops. Filled (open) symbols for lower (upper) hemisphere, with circles (triangles) indicating ChRM directions carried by hematite (magnetite), asterisk for present-day field direction in Central Germany.

higher unblocking temperature ranges (Fig. 4). Component $\mathrm{A}$, indicated by a relatively steep downward directed magnetization along the present-day field direction $\left(D=0^{\circ}, I \sim 66^{\circ}\right)$, is ascribed to a viscous overprint that is readily removed by either $400{ }^{\circ} \mathrm{C}$ or an alternating field of less than $20 \mathrm{mT}$. In all, about $18 \%$ of the samples exhibit exclusively this direction (Fig. 4f). Thus, no identifiable characteristic remanence of Triassic origin is apparently present in these samples, which are referred to as type II magnetizations.
After bedding tilt correction, the remaining component B yielded two antipodal groups of directions: northeasterly (southwesterly) declinations with shallow positive (negative) inclinations (Fig. $4 \mathrm{a}-\mathrm{d}$ ). About $82 \%$ of the samples are indicated by this direction regarded as the characteristic remanent magnetization (ChRM), i.e. type I magnetization, which in the red-brown specimens is isolated over an unblocking temperature range from 500 to $680{ }^{\circ} \mathrm{C}$, but most commonly above $600{ }^{\circ} \mathrm{C}$, indicating hematite as carrier of remanence (Fig. $4 a-b, d)$. In the gray

Table 1

Mean paleomagnetic directions from all studied outcrops

\begin{tabular}{|c|c|c|c|c|c|c|c|c|c|c|c|}
\hline \multirow[t]{2}{*}{ Section } & \multirow[t]{2}{*}{$\mathrm{N}_{1}, \mathrm{~N}_{2}$} & \multicolumn{4}{|c|}{ In situ directions } & \multicolumn{4}{|c|}{ Tilt corrected directions } & \multicolumn{2}{|l|}{ VGP } \\
\hline & & $\begin{array}{l}\mathrm{D} \\
\left({ }^{\circ}\right)\end{array}$ & $\begin{array}{l}\mathrm{I} \\
\left({ }^{\circ}\right)\end{array}$ & $\mathrm{k}$ & $\alpha_{95}$ & $\begin{array}{l}\mathrm{D} \\
\left({ }^{\circ}\right)\end{array}$ & $\begin{array}{l}\mathrm{I} \\
\left({ }^{\circ}\right)\end{array}$ & $\mathrm{k}$ & $\alpha_{95}$ & $\begin{array}{l}\text { Lat., Long. } \\
\left({ }^{\circ}\right)\end{array}$ & $\begin{array}{l}\mathrm{dp}, \mathrm{dm} \\
\left({ }^{\circ}\right)\end{array}$ \\
\hline Klingelbachtal & 32,25 & 25.1 & 17.0 & 8.6 & 11.2 & 24.9 & 24.5 & 14.1 & 8.5 & $47.8 \mathrm{~N}, 152.0 \mathrm{E}$ & $5.3,3.2$ \\
\hline Wüstenzell & 48,44 & 19.3 & 34.7 & 20.8 & 4.5 & 19.8 & 27.8 & 28.8 & 4.0 & $51.4 \mathrm{~N}, 157.9 \mathrm{E}$ & $2.4,4.5$ \\
\hline Karsdorf & 19,12 & 27.9 & 49.5 & 30.2 & 8.4 & 32.1 & 33.1 & 68.2 & 5.6 & $48.2 \mathrm{~N}, 142.3 \mathrm{E}$ & $3.6,6.3$ \\
\hline Fliegerrutsche & 24,14 & 28.3 & 39.8 & 4.7 & 20.7 & 28.2 & 28.7 & 12.3 & 11.8 & $47.6 \mathrm{~N}, 149.2 \mathrm{E}$ & $7.1,13.0$ \\
\hline Steudnitz & 29,16 & 313.2 & 71.9 & 6.8 & 16.5 & 22.0 & 24.5 & 27.5 & 6.7 & $47.9 \mathrm{~N}, 158.6 \mathrm{E}$ & $4.4,8.2$ \\
\hline Bad Karlshafen & 24,18 & 13.4 & 16.0 & 9.5 & 14.2 & 13.9 & 17.2 & 9.6 & 14.1 & $45.6 \mathrm{~N}, 169.5 \mathrm{E}$ & $7.6,14.6$ \\
\hline Overall direction & & 18.4 & 39.3 & 10.1 & 22.2 & 23.3 & 26.1 & 106.4 & 6.5 & $49.1 \mathrm{~N}, 154.1 \mathrm{E}$ & $3.8,7.1$ \\
\hline
\end{tabular}

$\mathrm{N} 1$, number of specimens demagnetized; N2, number of specimens used for statistical analysis; D, Declination; I, Inclination; k, precision parameter; $\alpha 95$, radius of cone of $95 \%$ confidence about the mean direction; Lat., Long., latitude and longitude of north paleomagnetic pole; dp, dm, semi-axes of the $\alpha 95$ confidence oval about the paleomagnetic pole. 
lithologies it is removed either over a temperature range of 500 to $590{ }^{\circ} \mathrm{C}$ or by alternating fields of less than $100 \mathrm{mT}$, which can be ascribed to magnetite (Fig. 4c, e). For the

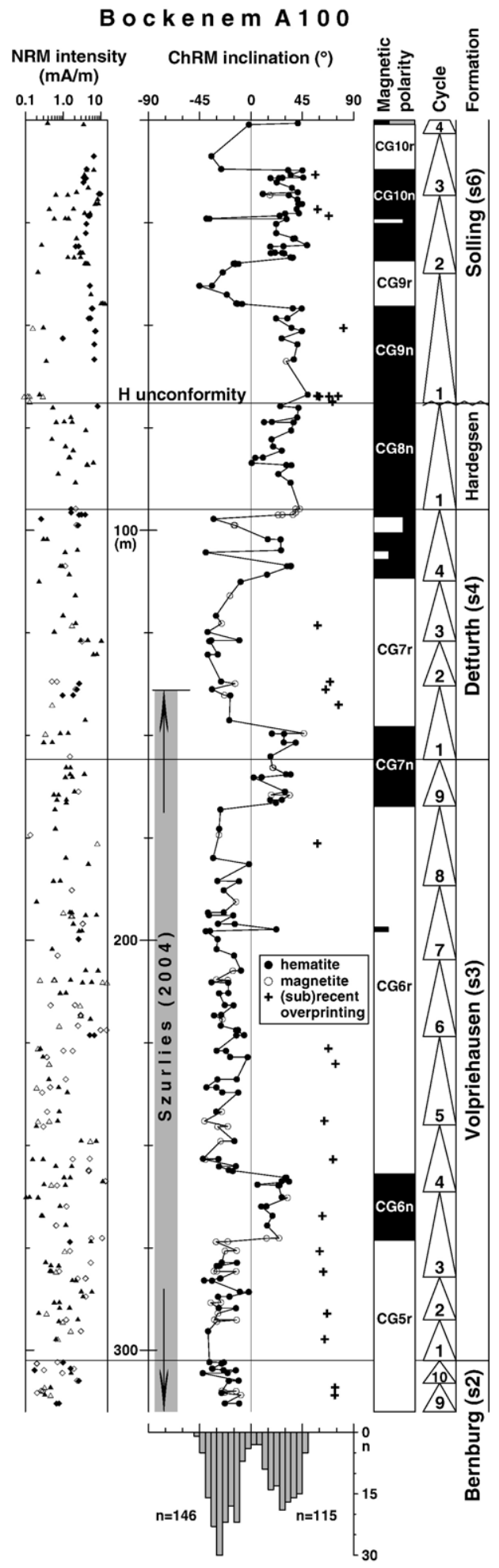

gray lithologies, calculations of the ChRM were typically based on five demagnetization steps in the interval of about 500 to $580^{\circ} \mathrm{C}$, whereas estimates for the red-brown samples were obtained from data between 600 and $680^{\circ} \mathrm{C}$, using least-squares line fits (Kirschvink, 1980).

Previous data indicate that a Triassic dual-polarity remanence is preserved in type I magnetizations (Szurlies et al., 2003; Szurlies, 2004) with 389 samples of the present study revealing this direction, which was used to construct a composite magnetostratigraphy. The mean normal and reversed ChRMs only slightly deviate from being antipodal with the normal directions having a tendency to be steeper and somewhat better grouped than the reversed directions (Fig. 5). This is most probably due to residual contaminations from overprint magnetizations, which in any case do not influence interpretation of polarity as well as determination of paleomagnetic poles since their biasing effect is minimized by averaging the directions in each section. The means of type I magnetizations pass the fold test with the ChRMs being significantly better grouped after tilt correction (Table 1). Consistent with previous data from the Buntsandstein (Szurlies et al., 2003; Szurlies, 2004) and close to the expected earliest Middle Triassic geomagnetic field direction for Central Germany (e.g. Van der Voo and Torsvik, 2004), the overall mean paleomagnetic direction from all studied outcrops is $D=23.3^{\circ}, I=26.1^{\circ}\left(\alpha 95=6.5^{\circ}\right)$. The virtual geomagnetic pole (VGP) at $49.1 \mathrm{~N}, 154.1 \mathrm{E}$ for the upper Buntsandstein is statistically the same as the Buntsandstein VGPs compiled by Van der Voo and Torsvik (2004).

\section{Geomagnetic polarity record for Central Germany}

The composite magnetostratigraphy of all studied sections has been constructed using directions from type I magnetizations with three or more successive samples of the same polarity defining a magnetozone. Thin polarity intervals that may occur within a magnetozone or those being indicated by only one or two horizons are ranked as submagnetozones. For identification of magnetozones, a nomenclature similar to the protocol erected for marine magnetic anomalies has been used (Cande and Kent, 1992).

Fig. 6. Magnetic record of Bockenem A100 core with NRM intensities and inclinations versus depth as well as histogram of ChRM inclinations using also data from Szurlies (2004). ChRMs carried by hematite (magnetite) are characterized by solid (open) symbols. Indicated by crosses are type II magnetizations revealing steep positive inclinations along the present-day field direction $\left(I \sim 66^{\circ}\right)$. For identification of magnetozones, the nomenclature established by Szurlies et al. (2003) is adopted with prefix CG to indicate Central Germany. See Fig. 1 for key. 


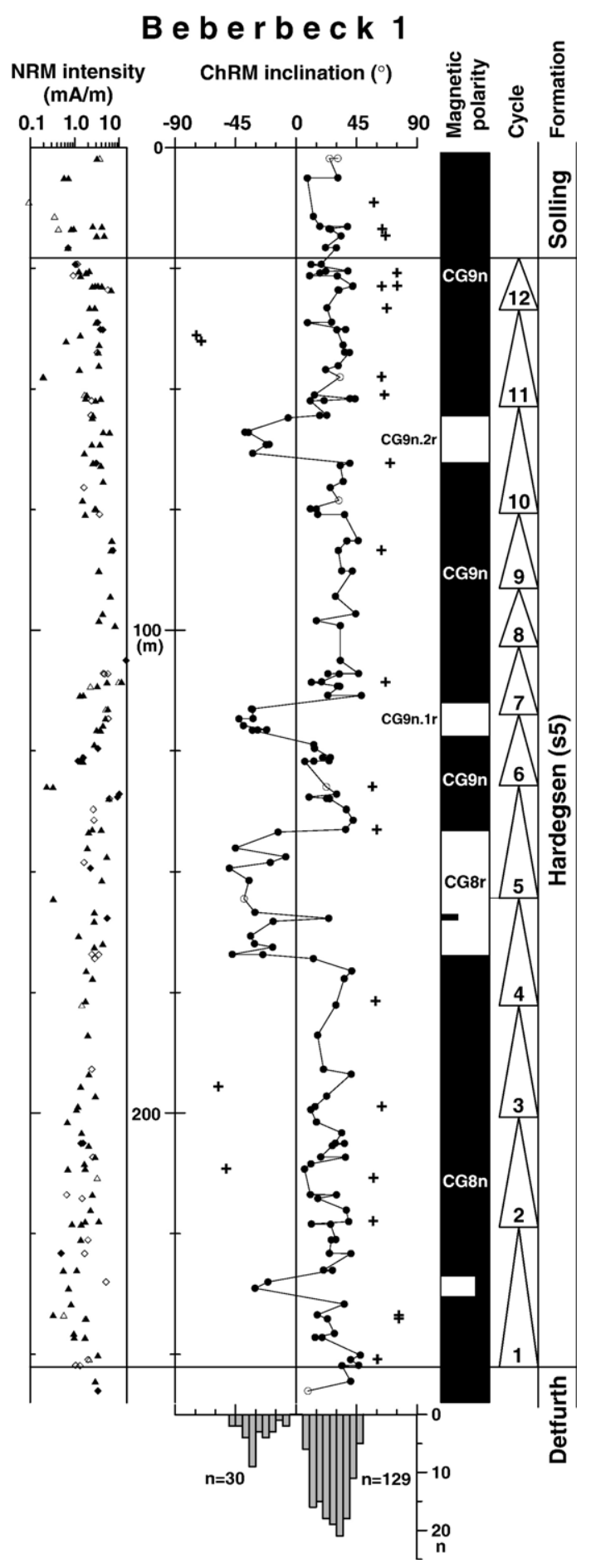

Fig. 7. Magnetic record of Beberbeck 1 core with NRM intensities and inclinations versus depth as well as histogram of ChRM inclinations. See Figs. 1 and 6 for key.

Recently, Szurlies (2004) presented a magnetic record for the lower Middle Buntsandstein, namely the Volpriehausen and lower Detfurth formations, derived mainly from the Bockenem A100 core (Figs. 1 and 6). For the present study, further 111 samples were collected from the overlying upper Detfurth to Solling formations of this core revealing predominantly normal polarity (Fig. 6). As already mentioned, the investigation of the Middle Buntsandstein is somewhat complicated by the presence of the $\mathrm{H}$ unconformity, which, for instance, is indicated by a significant hiatus in the Bockenem A100 core where the Solling Formation rests directly upon the lowermost Hardegsen Formation (Figs. 2 and 6). However, the missing stratigraphic interval was recovered in the Beberbeck 1 core (Figs. 1 and 7), which is located within the deepest part of the former Hessian Depression (Figs. 1 and 2). From this core, 184 samples were collected from the uppermost Detfurth to Solling formations revealing mainly normal polarity with three well-defined reversed intervals (CG8r, CG9n.1r, CG9n.2r) within the middle to upper Hardegsen Formation (Fig. 6). In both cores, the overlying lower Solling Formation is indicated by dominantly normal polarity (CG10n). Most of the following upper Solling Formation was sampled in the Bad Karlshafen section (Figs. 1 and 8) yielding in all 24 samples of predominantly reversed polarity (CG10r).

The Upper Buntsandstein to lowermost Muschelkalk was examined in five outcrops (Figs. 1 and 8) with the composite magnetic record being based on, in all, 152 samples. This stratigraphic interval reveals dominantly normal polarity with two thin reversed magnetozones, one at its base (CG10r) and one in its uppermost part (CG11r). The topmost normal interval CG12n of the Buntsandstein extends into the Muschelkalk.

From all sections a total of 10 magnetozones has been delineated (CG7r to CG12n). Combined with recently established records (Szurlies et al., 2003; Szurlies, 2004), a well-documented upper Zechstein to lowermost Muschelkalk magnetostratigraphy has been constructed (Fig. 9), now encompassing an overall stratigraphic thickness of about $1.3 \mathrm{~km}$ and in all 22 magnetozones, based on about 2050 samples from 16 outcrops and 6 cores. The polarity intervals have an average thickness of about $59 \mathrm{~m}$, ranging from 11 to $138 \mathrm{~m}$. Integrated with (GR) log-, cyclo-, and biostratigraphy, this multidisciplinary study enables detailed correlation within the CEB and, moreover, comparison with records from the marine Lower Triassic as well.

\section{Magnetostratigraphic correlation within the Central European Basin}

In the last decade, a considerable number of paleomagnetic studies focused on the Buntsandstein in 

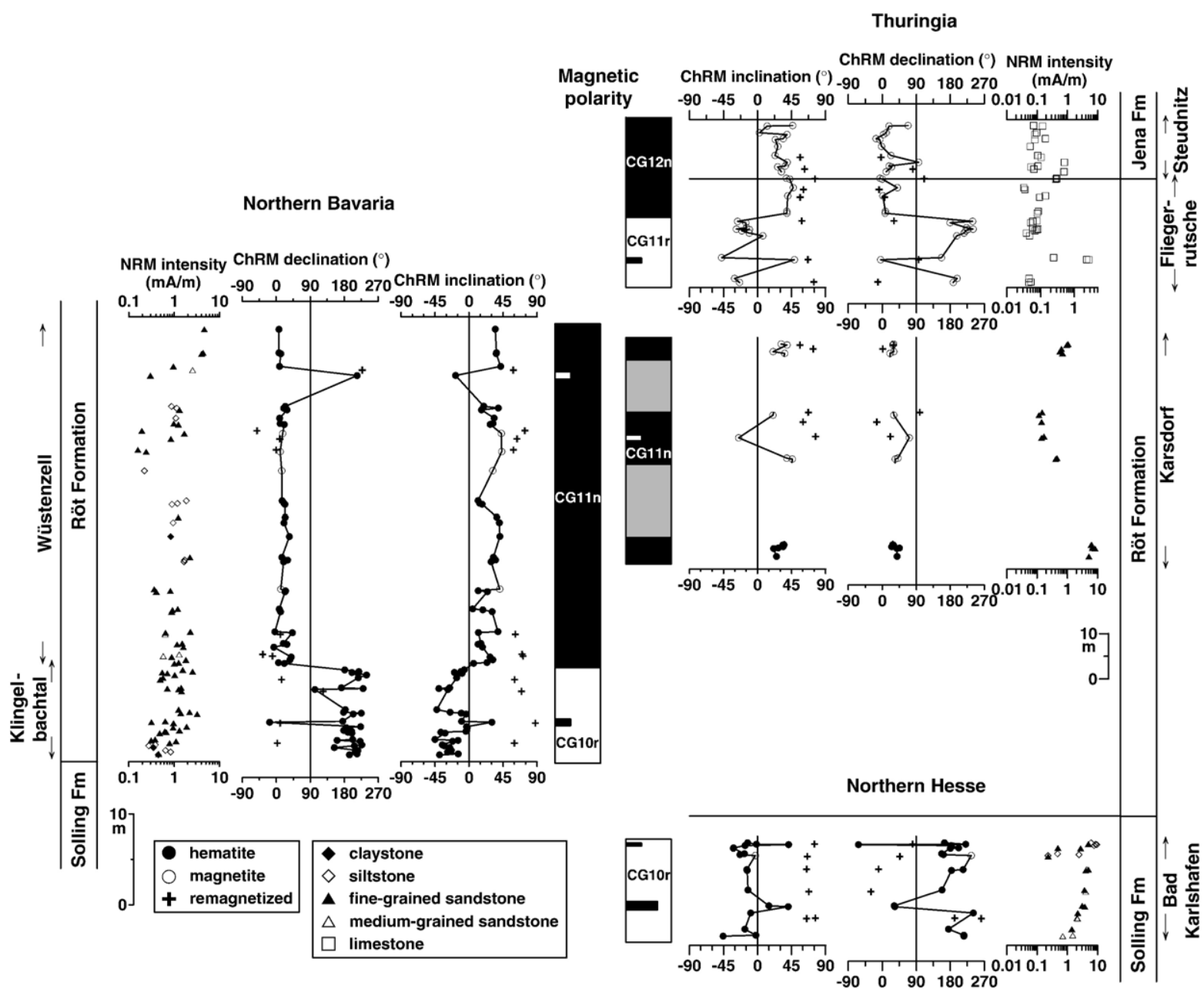

Fig. 8. Composite magnetic record of uppermost Middle Buntsandstein to lowermost Muschelkalk from Central Germany compiled from 6 outcrops. See Figs. 1 and 6 for key.

different parts of the CEB (e.g. Nawrocki, 1997; Soffel and Wippern, 1998; Nawrocki and Szulc, 2000; Szurlies et al., 2003; Szurlies, 2004; Dinarès-Turell et al., 2005), in which Nawrocki (1997) and Soffel and Wippern (1998) presented magnetic records for the entire Buntsandstein from Poland and South Germany, respectively. The correlation of the latter with the Central German composite reveals close similarities concerning the number of magnetozones, their relative thickness as well as the overall polarity pattern (Fig. 9).

Consistent with (GR) log- and lithostratigraphic comparison (e.g. Roman, 2004; Geluk, 2005), the detailed magnetostratigraphic correlation with the Polish record indicates the German Lower Buntsandstein to be equivalent to the Baltic Formation (Szurlies et al., 2003) with the base of the Buntsandstein falling within the lower part of a relatively thick normal polarity interval (CG3n, Tbn1). From the mutual agreement of magnetozones and lithostratigraphic units can be deduced that the latter seemingly provide synchronous horizons for correlation, at least, within the interior of the CEB (compare Szurlies et al., 2003).

The mainly reversed (CG5r to CG7r) Volpriehausen and Detfurth formations obviously correspond to Tbr3 to Tbr5 from the Pomorska and lowermost Polczyn formations (compare Szurlies, 2004), and the overlying Hardegsen to lower Solling formations, which are indicated by a thick interval of predominantly normal polarity (CG8n to CG10n), are most likely equivalent to Tbn6 and lower Tbn7, spanning most of the Polish upper Middle Buntsandstein. The correlation of the following uppermost Middle Buntsandstein is less clear mainly because the reversed polarity interval CG10r is apparently absent in the Polish composite 


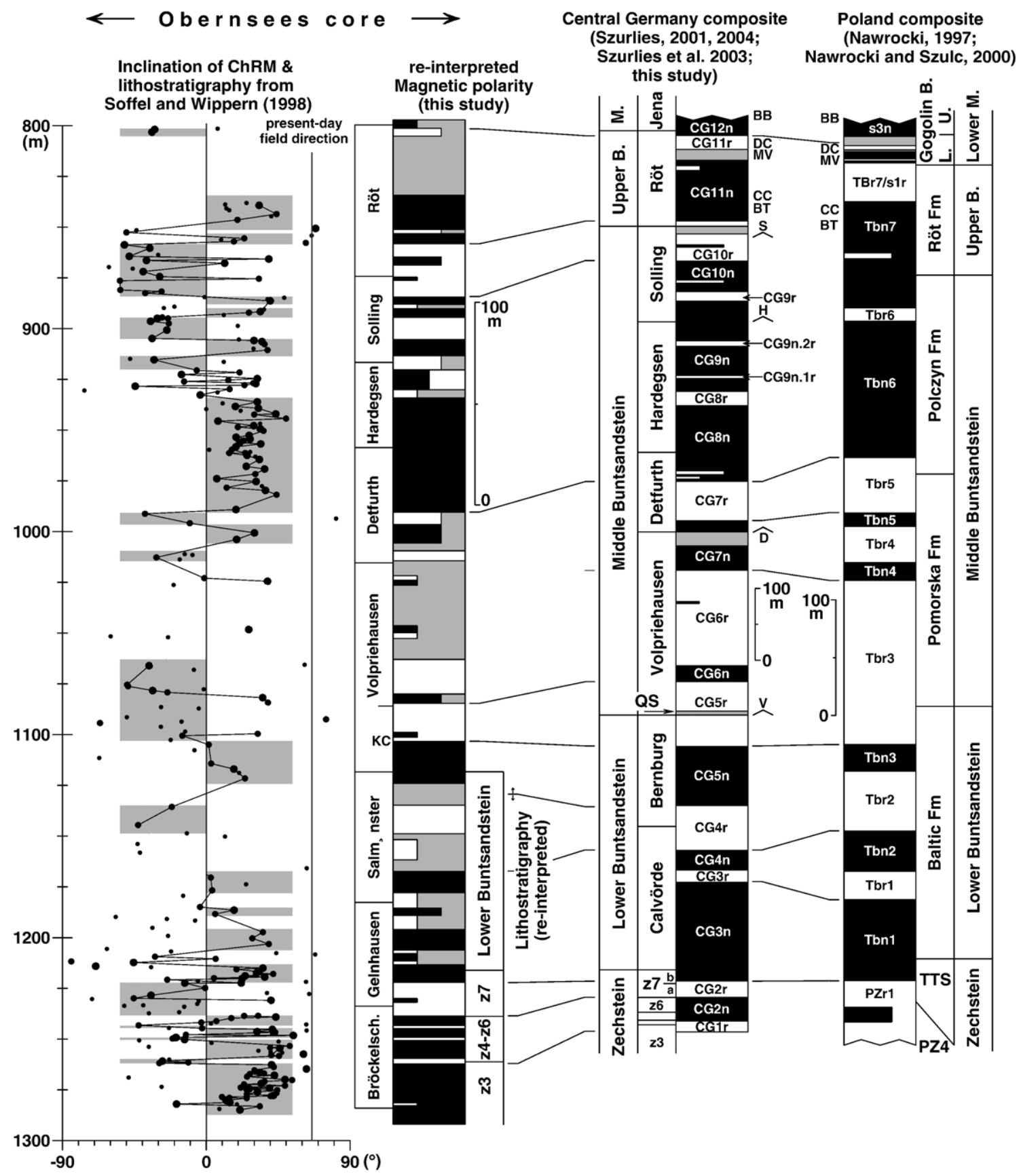

Fig. 9. Comparison of Buntsandstein litho- and magnetostratigraphies from Poland (Nawrocki, 1997; Nawrocki and Szulc, 2000), Central Germany, and South Germany (Soffel and Wippern, 1998), in which the lithostratigraphy and the paleomagnetic data of the latter were re-interpreted in this study (K.-C. Käding, pers. comm.). KC = Kulmbach Conglomerate, TTS = Top Terrigenous Series; BT = Beneckeia tenuis, $\mathrm{CC}=$ Costatoria costata, $\mathrm{MV}=$ Myophoria vulgaris, $\mathrm{DC}=$ Dadocrinus, $\mathrm{BB}=$ Beneckeia buchi. See Fig. 1 for key.

(Fig. 9). This is most likely due to the low sampling resolution within this interval in the Polcyzn IG-1 and Otyn IG-1 cores studied by Nawrocki (1997). From the latter, Nawrocki (1997) obtained a reversed horizon
(Tbr6) in an interval slightly below the base of the Upper Buntsandstein that according to Fuglewicz (1980) is equivalent to the German Solling Formation, suggesting a correspondence to CG10r. However, based 


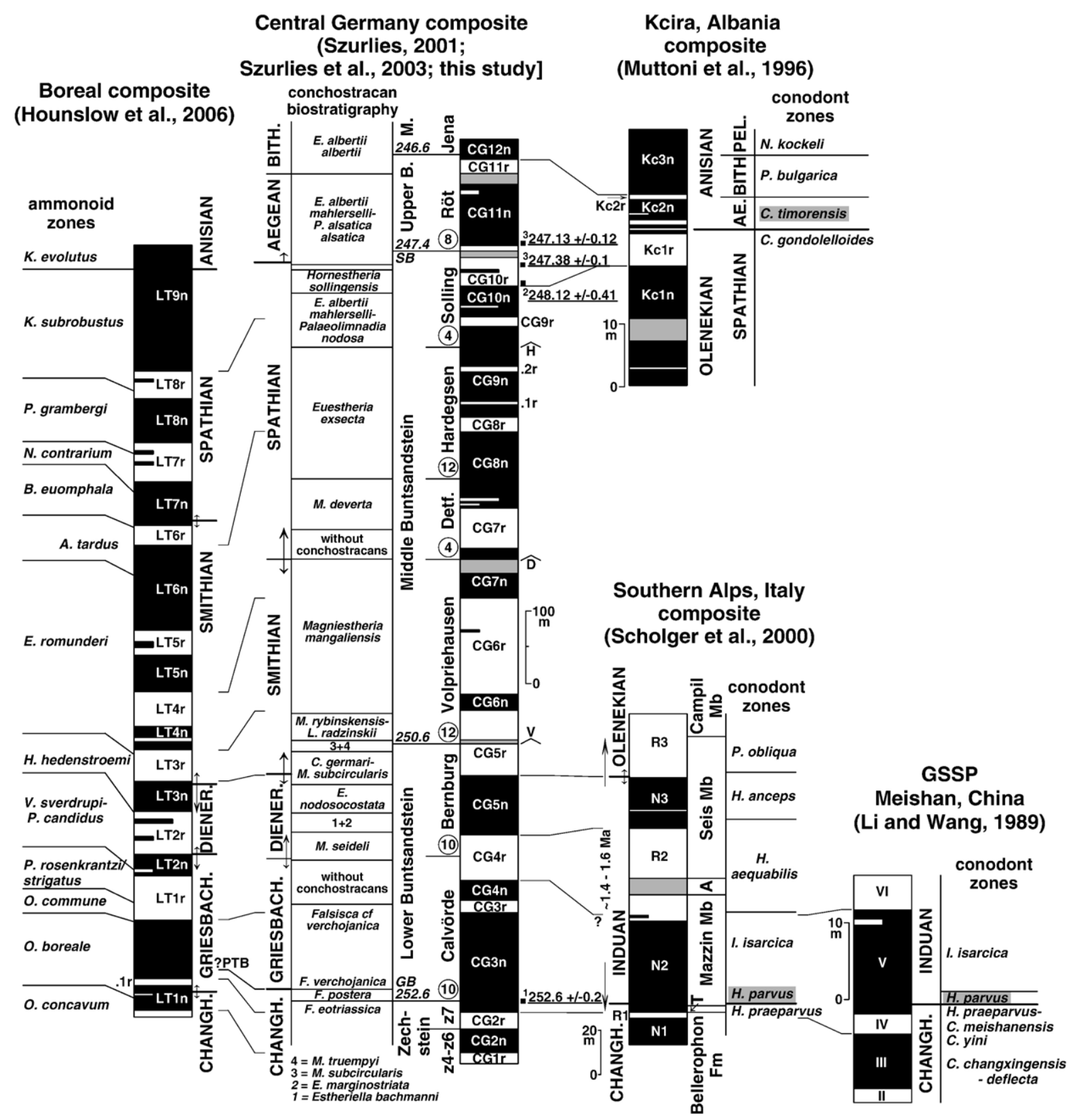

Fig. 10. Comparison of Central German composite conchostracan biostratigraphy (Kozur, 1999; Bachmann and Kozur, 2004) and magnetostratigraphy (on the left) with biostratigraphically calibrated magnetic records from the Boreal (Hounslow et al., 2006) and Tethyan realms (Li and Wang, 1989; Muttoni et al., 1996; Scholger et al., 2000), in which the biostratigraphy of the Southern Alps sections is taken from Farabegoli and Perri (1998). ' age of 252.6 Ma for the PTB (Mundil et al., 2004) was used to anchor the Buntsandstein cyclostratigraphy (estimated ages are shown in italics within the Buntsandstein column), ${ }^{2}$ radioisotopic age from (Ovtcharova et al., 2006), ${ }^{3}$ radioisotopic age from (Lehrmann et al., 2006). GB = Gray Beds, $\mathrm{SB}=$ Stammen Beds, $\mathrm{T}=$ Tesero Oolite, $\mathrm{A}=$ Andraz Horizon, $\mathrm{AE}=$ Aegean, $\mathrm{BITH}=\mathrm{Bithynian}, \mathrm{PEL}=\mathrm{Pelsonian}$, M. = Muschelkalk. See Fig. 1 for key.

on between-site correlation with the Polczyn IG-1 section, Nawrocki (1997) placed Tbr6 in the Polish composite somewhat deeper within the upper Middle Buntsandstein (Fig. 9).
The overlying marine influenced German Röt Formation corresponds to the Polish Upper Buntsandstein and the overlying Lower Gogolin Beds (e.g. Kozur, 1999; Geluk, 2005), which in the Polish nomenclature 
already belong to the Muschelkalk. In both records, the lower Röt Formation is indicated by a fauna with the ammonoid Beneckeia tenuis and the bivalve Costatoria costata, whereas the German upper Röt Formation and the Polish uppermost Buntsandstein to Lower Gogolin Beds contain the ammonoid B. buchi, the bivalve Myophoria vulgaris among others (Bachmann and Kozur, 2004). In accordance with biostratigraphy, CG11n, CG11r, and CG12n are most probably equivalent to Tbn7, Tbr7 and lower S3n (Fig. 9).

The comparison with the original Obernsees magnetic polarity record from the southern margin of the CEB (Figs. 1 and 9 Soffel and Wippern, 1998) reveals almost double the number of magnetozones compared to the Central German and Polish composites (Fig. 9). Most probably, that can be put down to the fact that Soffel and Wippern (1998) defined 11 single-sample polarity intervals and further 18 magnetozones based on only two specimens, which are displayed here as one third or two thirds of a bar, respectively (Fig. 9). Using this reinterpretation, the main features of the Central German polarity pattern are readily visible, for instance the mixed polarity of the Lower Buntsandstein or the predominantly normal upper half of the Middle Buntsandstein. In agreement with the Central German composite, the upper Solling to lowermost Röt formations are indicated by a reversed polarity interval (CG10r), providing further constraints on the presence of a reversed interval across the base of the Upper Buntsandstein.

In addition, the magnetostratigraphic correlation with the Obernsees record reveals a diachronous character of the lithostratigraphic units towards the margin of the CEB, for instance the base of the Volpriehausen Formation that falls within a reversed magnetozone (CG5r) in the interior of the $\mathrm{CEB}$, but in a normal interval at the Obernsees site. Most probably, the latter corresponds to CG5n implying most of the Kulmbach Conglomerate at the base of the Volpriehausen Formation to be actually contemporaneous with the upper Bernburg Formation of Central Germany.

\section{Global correlation of the Buntsandstein and calibration of the Early Triassic stages and substages}

\subsection{PTB and Induan stage}

For the Lower and Middle Buntsandstein, conchostracans (bivalved crustaceans) and sporomorphs provide the best presently available biostratigraphic ties to the ammonoid- and conodont-calibrated Boreal and Tethyan Lower Triassic (e.g. Kozur, 1999; Bachmann and Kozur, 2004 and references therein). According to Kozur (1999), the Hindeodus parvus (conodont) calibrated PTB is placed at the base of the Falsisca verchojanica conchostracan Zone within the "Graubankbereich" (=Gray Beds) of the Lower Buntsandstein (Figs. 9 and 10). Consequently, the underlying lowermost Buntsandstein that belongs to the $F$. postera Zone is latest Permian in age, what agrees with vertebrate stratigraphy from the Dalongkou section (NW China) where F. postera occurs together with Lystrosaurus and Dicynodon slightly below the PTB (Kozur, 1999). In the Karoo Basin (South Africa), the LAD of Dicynodon is in the lower part of a thick normal polarity interval (Ward et al., 2005), which, in turn, is consistent with Buntsandstein magnetostratigraphy where the assumed PTB falls within a remarkable thick normal magnetozone (CG3n) as well (Fig. 10, Szurlies et al., 2003). Obviously, the latter is a distinctive feature visible in virtually all magnetic records across the PTB (e.g. Heller et al., 1988; Steiner et al., 1989; Ogg and Steiner, 1991; Nawrocki, 1997; Scholger et al., 2000; Gallet et al., 2000; Szurlies et al., 2003; Tong et al., 2004; Szurlies and Kozur, 2004; Ward et al., 2005) including the Global Stratotype Section and Point (GSSP) of the PTB in Meishan (S China) (Li and Wang, 1989).

Most probably due to partial remagnetization, there are substantive differences between the PTB magnetostratigraphies that have been established in China, so that even studies performed in the same section, partly, display different magnetic records, for instance in Shangsi (Heller et al., 1988; Steiner et al., 1989) and Meishan (Li and Wang, 1989; Zhu and Liu, 1999). At Meishan, the finding of a brief reversed polarity interval that straddles the PTB (Zhu and Liu, 1999) has not been validated by a recent re-sampling (H. Yin, pers. comm., in Bachmann and Kozur, 2004). Instead of that, it largely substantiates the thick normal magnetozone (V) across the PTB, postdating a thin reversed polarity interval, as originally established by Li and Wang (1989) (Fig. 10). Referring to the Shangsi magnetostratigraphy where the PTB predates a further brief reversed interval (Heller et al., 1988; Steiner et al., 1989), Hounslow et al. (2006) recently equated the latter with LT1n.1r from their Boreal composite and CG2r from the Central German composite implying a position of the PTB within underlying CG2n (Fig. 10). However, such a reversed interval, postdating the base of the Triassic, is absent in practically all other PTB magnetostratigraphies (e.g., Li and Wang, 1989; Ogg and Steiner, 1991; Scholger et al., 2000; Gallet et al., 2000) including the continental records (Nawrocki, 1997; Szurlies et al., 2003; Ward et al., 2005) that due to their relatively high rates of sedimentation originally provided favourable prerequisites for recording even briefest magnetozones. 
Consequently, it seems to be more conclusive to place the PTB in a level slightly above LT1n.1r within the following distinctive normal polarity interval (LT1n, Hounslow et al., 2006; V1n, Mørk et al., 1999), what biostratigraphically falls within the Otoceras boreale ammonoid Zone or at the top of the Lundbladispora obsoleta-Tympanicysta stoschiana miospore Assemblage Zone (Mørk et al., 1999). The latter most probably corresponds to the latest Permian L. obsoleta-Lunatisporites noviaulensis A.Z. from the lowermost Buntsandstein and the lowermost Werfen Formation, respectively (see Kozur, 1999; Bachmann and Kozur, 2004 and references therein). This alternative correlation is in good accordance with carbon isotope data from Spitsbergen (Wignall et al., 1998) and Greenland (Twitchett et al., 2001) in that a distinctive negative anomaly is intimately associated with a palynofloral turnover that on Spitsbergen occurs at the base of the latest Permian L. obsoleta-T. stoschiana A.Z. considerably below the FAD of $H$. parvus (Twitchett et al., 2001). Such a carbon isotope excursion predating the PTB is a well-documented feature in both marine and continental environments (e.g. (Ward et al., 2005; Yin et al., 2006), including the CEB (Hiete, 2004; Korte and Kozur, 2006).

Most of the overlying Lower Buntsandstein is equivalent to the Induan with polarity intervals CG3n and CG5n corresponding to N2 and N3 from the Southern Alps composite (Scholger et al., 2000) and most of LT1n and LT3n from the Boreal composite (Hounslow et al., 2006) (Fig. 10) among others. In terms of magnetostratigraphy, the Calvörde Formation reveals mainly normal polarity what is a common feature of practically all Griesbachian magnetic records world-wide (e.g. Li and Wang, 1989; Steiner et al., 1989; Nawrocki, 1997; Scholger et al., 2000; Gallet et al., 2000; Ward et al., 2005; Hounslow et al., 2006). Biostratigraphically, the base of the Dienerian is located either close to the base or around the top of the Molinestheria seideli Zone (Bachmann and Kozur, 2004; Kozur, 2006).

Recently, the base of the Olenekian has been proposed to be marked by either the FAD of the ammonoid Rohillites rohilla (Bhargava et al., 2004) or alternatively the FAD of the conodont Neospathodus waageni (Tong et al., 2004). The latter falls within the uppermost part of a normal polarity interval (Tong et al., 2004) that most probably corresponds to CG5n implying a position of the Induan-Olenekian boundary within the upper Bernburg Formation (Hauschke and Szurlies, 2006) (Fig. 10), what is considerably deeper than hitherto assumed (Szurlies et al., 2003; Szurlies, 2004). Biostratigraphically, this level is somewhat below a turnover in the conchostracan faunas, where the spined forms (e.g., Cornia germari) are replaced by large conchostracans without spines (e.g., Magniestheria truempyi) (Kozur, 2006). According to Kozur (Kozur, 1999, 2006), the spined C. germari is known, for instance, from brackish intercalations within the Late Induan Claraia aurita Zone of the marine Werfen Formation (Hungary), whereas the large $M$. truempyi occurs in the overlying part of this formation that is indicated by an undoubtedly Early Olenekian Pachycladina conodont fauna.

\subsection{Olenekian stage and Lower-Middle Triassic boundary}

Magnetostratigraphically, the relatively thick magnetozone CG8n, spanning the upper Detfurth to lower Hardegsen formations, most likely corresponds to LT6n from the Boreal composite implying a Smithian age for the uppermost Bernburg to lower Hardegsen formations (Fig. 10). However, this apparently violates with established biostratigraphic correlation to the Tethyan scale, in that the Smithian-Spathian boundary is assumed to be located within the Detfurth Formation (Kozur, 1999) or even close to its base (Bachmann and Kozur, 2004). Relative to magnetostratigraphic correlation with the Buntsandstein record, there is obviously an offset in that the Spathian in the Tethyan scale is seemingly significantly longer than the originally ammonoidcalibrated Boreal Spathian what has recently been confirmed by radioisotopic ages obtained from Tethyan strata, implying a rather long Spathian (Ovtcharova et al., 2006). However, for this interval the conchostracanbased correlation is not well constrained.

The overlying mainly marine Upper Buntsandstein to Lower Muschelkalk already contain an Anisian fauna, e.g. the ammonoids Beneckeia tenuis, B. buchi, and Balatonites ottonis as well as the conodont Nicoraella kockeli among others, providing reliable biostratigraphic ties to the marine Middle Triassic (e.g. Kozur, 1999; Bachmann and Kozur, 2004). The Lower-Middle Triassic boundary, i.e. the base of the Anisian is proposed to be located at the FAD of the conodont Chiosella timorensis, falling within the uppermost part of a mainly reversed interval (e.g., Kc1r Muttoni et al., 1996) that most probably corresponds to CG10r (Fig. 10). Consequently, the overlying predominantly normal Upper Buntsandstein is Early Anisian in age revealing a good match with biostratigraphy based on ammonoids, bivalves, and crinoids among others (compare Bachmann and Kozur, 2004 and references therein). Furthermore, the sporomorph association of the Upper Buntsandstein is indicated by the Anisian index species Stellapollenites thiergartii among others (Visscher et al., 1993). In the 
recent Boreal composite that is mainly derived from central Spitsbergen (Mørk et al., 1999), the base of the Anisian is located within a thick normal magnetozone (LT9n) (Hounslow et al., 2006). However, the magnetostratigraphy from Arctic Canada reveals significantly more reversed polarity around the Olenekian-Anisian boundary (Ogg and Steiner, 1991) implying the occurrence of a hiatus close to the base of the Anisian in the Boreal realm (e.g. Ogg and Steiner, 1991; Hounslow et al., 2006, M.W. Hounslow, pers. comm.). Further explanations for this discrepancy include a low sampling resolution of this interval on Spitsbergen (Mørk et al., 1999) and the assumption that this interval experienced partial remagnetization (Mørk et al., 1999; Hounslow et al., 2006).

Biostratigraphically, the base of the ensuing Bithynian is placed within the uppermost Buntsandstein (e.g., Kozur, 1999) falling within a thin reversed polarity interval (CG11r, Kc2r) that obviously represents a firstorder marker for this substage boundary (Fig. 10). However, exclusively based on magnetostratigraphic correlation, Nawrocki and Szulc (2000) previously placed the base of the Anisian significantly higher within magnetozone S1r of the Polish uppermost Röt Formation (Fig. 9). Hence, they derived an Olenekian age for most of the Upper Buntsandstein what clearly violates with any biostratigraphic correlation as well as magnetostratigraphic comparison presented here (Figs. 9 and 10). As mentioned earlier, it appears that an interval equivalent to CG10r is most probably undetected in the Polish sections (Nawrocki, 1997), so that the mainly reversed interval S1r to S2r more likely correlates with CG11r closely matching with biostratigraphy.

\subsection{Calibration of the Early Triassic stages and substages}

Based on an integrated biomagnetostratigraphic comparison, radioisotopic ages obtained from Tethyan sections, can be referred to the Buntsandstein cyclostratigraphy in order to validate or falsify the hypothesis that the pronounced small-scale cycles correspond to solar-induced $\sim 100$ ka eccentricity cycles. Assuming that these about 60 cycles represent such short eccentricity cycles, the duration of the Buntsandstein has recently been calculated to span some $6 \mathrm{Ma}$ (Szurlies, 2005) or $6.7 \mathrm{Ma}$ (Bachmann and Kozur, 2004) what is considerably shorter than hitherto assumed (e.g. 11 Ma Menning, 1995; Geluk and Röhling, 1997, 8 Ma DSK, 2002).

Using an age of $252.6+/-0.2 \mathrm{Ma}$ for the PTB (Mundil et al., 2004) to anchor the Buntsandstein cyclostratigraphy, the Buntsandstein/Muschelkalk boundary was dated at $\sim 246.7$ and the base of the Anisian at $\sim 247.5 \mathrm{Ma}$
(Szurlies, 2005), respectively. This matches closely with more recent radioisotopic ages obtained from Tethyan ash beds of South China around the Olenekian-Anisian boundry (Ovtcharova et al., 2006; Lehrmann et al., 2006), implying an age of $\sim 247.2$ Ma for the base of the Anisian (Lehrmann et al., 2006). Thus, it largely substantiates the hypothesis of short eccentricity cycles. However, due to probably missing cycles below the prominent $\mathrm{H}$ unconformity, a slightly longer duration of the Olenekian, i.e. a somewhat younger age for the Olenekian-Anisian boundary of some $\sim 100$ ka cannot be ruled out entirely. Based on new radioisotopic ages around the OlenekianAnisian boundary, the Early Triassic has been calculated to span 4.5+/-0.6 Ma (Ovtcharova et al., 2006) or about $5 \mathrm{Ma}$ (Lehrmann et al., 2006), respectively, what is consistent with duration of about 5 Ma (Szurlies, 2005) previously derived from cyclostratigraphic calibration of the coeval Buntsandstein strata. For the Buntsandstein, it reveals rates of sedimentation of $\sim 150 \mathrm{~m} / \mathrm{Ma}$ as well as a mean magnetozone duration of $\sim 0.3 \mathrm{Ma}$, ranging from less than 0.1 to $\sim 0.7 \mathrm{Ma}$.

Accordingly, the Buntsandstein cyclostratigraphy is used here to tentatively calibrate the marine stages and substages, implying duration of about 1.5 Ma for the Induan with the Griesbachian probably spanning some $0.9 \mathrm{Ma}$, and the Dienerian lasting $\sim 0.6 \mathrm{Ma}$ what is in agreement with data obtained by Ovtcharova et al. (2006). Furthermore, this is almost consistent with duration of $\sim 1.4$ to $1.6 \mathrm{Ma}$ obtained from time-series analysis of the lower Werfen Formation (Tesero Oolite to Seis Member) from the Southern Alps (Rampino et al., 2000), which according to biomagnetostratigraphic correlation is nearly equivalent to the Lower Buntsandstein (Fig. 10). For the ensuing Olenekian, duration of 3.3 to $3.5 \mathrm{Ma}$ has been derived with the Smithian spanning $\sim 1.6 \mathrm{Ma}$ and the Spathian lasting about 1.9 Ma. For the following Aegean substages that already belongs to the Anisian and corresponds to most of the Upper Buntsandstein, duration of about $0.8 \mathrm{Ma}$ has been calculated.

In summary, the Buntsandstein cyclostratigraphy obviously offers good potential to constructing a reliable astronomically calibrated Early Triassic geomagnetic polarity timescale. However, further test is needed to validate the hypothesis that the hierarchy of cycles of the Buntsandstein falls within the Milankovitch frequency band, using, above all, time-series analysis.

\section{Conclusions}

The paleomagnetic signal form the Buntsandstein preserves a dual-polarity magnetization with the consistent correlation of lithostratigraphic units and magnetozones 
on a scale of some $100 \mathrm{~km}$ supporting an early acquisition of the ChRMs in both, the magnetite-bearing gray lithologies as well as the hematite-bearing redbrown samples. In all, 10 magnetozones have been delineated from type I magnetizations obtained from 6 outcrops and 2 wells. Together with published magnetostratigraphies, the inter-section correlation allows the establishment of a geomagnetic polarity record for the uppermost Zechstein to lowermost Muschelkalk (latest Permian to Middle Triassic) encompassing 22 welldefined magnetozones. The comparison with composites from the CEB and, moreover, the marine Boreal and Tethyan realms reveals close similarities concerning the number of magnetozones and the overall polarity pattern, for instance the dominance of normal polarity in the upper Lower Triassic.

Based on an integrated biomagnetostratigraphy, the PTB is most probably located in the thick normal polarity interval CG3n, which is a distinctive feature of magnetic records across the PTB. Furthermore, the correlation provides evidence that the proposed InduanOlenekian boundary is located in the upper Bernburg Formation within the uppermost CG5n. The base of the ensuing Anisian is situated in magnetozone CG10r within the uppermost Solling Formation, i.e slightly below a reversal to dominantly normal polarity (CG11nCG12n), and the Aegean-Bithynian boundary is located in the uppermost Röt Formation within CG11r. Obviously, the polarity record provides primary markers to indicate the position of these boundaries.

Based on a comprehensive log- and lithostratigraphic study, the Buntsandstein consists of about 60 cycles, which are assumed to reflect water depth variations in the lacustrine system of the CEB most likely due to solarinduced short eccentricity cycles. These cycles have been mapped successfully by litho- and magnetostratigraphic means, obviously, providing synchronous units, at least, in the interior of the CEB. In terms of cyclostratigraphy, the Buntsandstein is estimated to span $\sim 6 \mathrm{Ma}$. Anchored to an age of $\sim 252.6 \mathrm{Ma}$ for the PTB, the Early Triassic is calculated to span $\sim 5 \mathrm{Ma}$, deriving an age of $\sim 247.5 \mathrm{Ma}$ for the base of the Anisian. The latter is consistent with recent radioisotopic ages available for the Lower-Middle Triassic boundary implying an age of $\sim 247.2 \mathrm{Ma}$. From the biomagnetostratigraphic correlation results a short Induan with duration of $\sim 1.5 \mathrm{Ma}$ and a considerably longer Olenekian lasting 3.3 to $3.5 \mathrm{Ma}$. Hence, the Buntsandstein is assumed to offer good potential for calibration of marine stages and substages as well as for development of an astronomically calibrated Early Triassic geomagnetic polarity timescale.

\section{Acknowledgments}

The author thanks H.W. Kozur, G.H. Bachmann, M. Menning, N.R. Nowaczyk, K.-C. Käding, H.G. Röhling, and M.W. Hounslow for valuable discussions, and C. Müller and D. Michalk for assistence during field work. I thank two anonymous reviewers for constructive revision of the manuscript. I am much indebted to the Wirtschaftsverband Erdöl- und Erdgasgewinnung (W.E.G.) for permission to publish the GR logs of the Brüggen $\mathrm{Z1}$ and Königslutter $Z 1$ wells. This study was funded by the Deutsche Forschungsgemeinschaft (projects: SZ 104/1-1, SZ 104/1-2) and contributes to the project group on "The Pan-European correlation of the epicontinental Triassic".

\section{References}

Bachmann, G.H., Kozur, H.W., 2004. The Germanic Triassic: correlation with the international chronostratigraphic scale, numerical ages, Milankovitch cyclicity. Hallesches Jahrb. Geowiss., B 26, 17-62.

Bhargava, O.N., Krystyn, L., Balini, M., Lein, R., Nicora, A., 2004. Revised litho- and sequence stratigraphy of the Spiti Triassic. Albertiana 30, 21-39.

Boigk, H., 1959. Zur Gliederung und Fazies des Buntsandsteins zwischen Harz und Emsland. Geol. Jb. 76, 597-636.

Cande, S.C., Kent, D.V., 1992. A new geomagnetic polarity time scale for the late Cretaceous and Cenozoic. J. Geophys. Res. 97, 13917-13951.

Dinarès-Turell, J., Diez, J.B., Rey, D., Arnal, I., 2005. "Buntsandstein" magnetostratigraphy and biostratigraphic reappraisal from eastern Iberia: Early and Middle Triassic stage boundary definitions through correlation to Tethyan sections. Palaeogeogr. Palaeoclimatol. Palaeoecol. 229, 158-177.

DSK, 2002. Deutsche Stratigraphische Kommission, Stratigraphische Tabelle von Deutschland 2002. 16 pp.

Erwin, D.H., 1993. The Great Paleozoic Crisis: Life and Death in the Permian. Columbia Univ. Press, New York, NY. 327 pp.

Farabegoli, E., Perri, M.C., 1998. Permian/Triassic boundary and Early Triassic of the Bulla section (Southern Alps, Italy): lithostratigraphy, facies and conodont biostratigraphy. G. Geol. 3, 292-311.

Fuglewicz, R., 1980. Stratigraphy and palaeogeography of Lower Triassic in Poland on the bassis of megaspores. Acta Geol. Pol. 30, 417-470.

Gallet, Y., Krystyn, L., Besse, J., Saidi, A., Ricou, L.E., 2000. New constraints on the Upper Permian and Lower Triassic geomagnetic polarity timescale from the Abadeh section (central Iran). J. Geophys. Res. 105, 2805-2815.

Geluk, M., 2005. Stratigraphy and tectonics of Permo-Triassic basins in the Netherlands and surrounding areas, PhD thesis Univ. Utrecht, $171 \mathrm{pp}$.

Geluk, M.C., Röhling, H.G., 1997. High-resolution sequence stratigraphy of the Lower Triassic "Buntsandstein" in the Netherlands and northwestern Germany. Geol. Mijnb. 76, 227-246.

Gradstein, F.M., Ogg, J.G., Smith, A.G., 2004. A Geologic Time Scale 2004. Cambridge Univ. Press. 589 pp.

Hauschke, N., Szurlies, M., 2006. Kontinentale Perm-Trias-Grenze und Buntsandstein nördlich von Halle (Saale) - Fazies, Bio-, Log-, Zyklen- und Magnetostratigraphie (Exkursion M am 22. April 2006). Jahresber. Mitt. Oberrhein. Geol. Ver., N.F. 88, 427-452. 
Heller, F., Lowrie, W., Li, H., Wang, J., 1988. Magnetostratigraphy of the Permo-Triassic boundary section at Shangsi (Guangyuan, Sichuan Province, China). Earth Planet. Sci. Lett. 88, 348-356.

Hiete, M., 2004. Umweltveränderungen in der Permo-Trias, PhD thesis Univ. Braunschweig, $330 \mathrm{pp}$.

Hounslow, M.W., McIntosh, G., 2003. Magnetostratigraphy of the Sherwood Sandstone Group (Lower and Middle Triassic), south Devon, UK: detailed correlation of the marine and non-marine Anisian. Palaeogeogr. Palaeoclimatol. Palaeoecol. 193, 325-348.

Hounslow, M.W., Peters, C., Mork, A., Weitschat, W., Vigran, O., 2006. Magneto-biostratigraphy of the Vikinghøgda Fm. Central Svalbard and the geomagnetic polarity timescale for the Lower Triassic. NGF Abstr. Proceed., vol. 3, pp. 61-63.

Kirschvink, J.L., 1980. The least-squares line and plane and the analysis of palaeomagnetic data. Geophys. J. R. Astron. Soc. 62, 699-718

Korte, C., Kozur, H.W., 2006. Carbon isotope trends in continental lake deposits of uppermost Permian to Lower Olenekian: Germanic Lower Buntsandstein (Calvörde and Bernburg Formations). Hallesches Jahrb. Geowiss., B Beih. 19, 87-94.

Kozur, H.W., 1999. The correlation of the Germanic Buntsandstein and Muschelkalk with the Tethyan scale. Zbliz. Geol. Paläontol. Part I 1998 7-8, 701-725.

Kozur, H.W., 2006. Remarks to the base of Olenekian. Albertiana 34, 66-72.

Lehrmann, D.J., Ramezani, J., Bowring, S.A., Martin, M.W., Montgomery, P., Enos, P., Payne, J.L., Orchard, M.J., Wang, H., Wei, J., 2006. Timing of recovery from the end-Permian extinction: Geochronologic and biostratigraphic constraints from south China. Geology 34, 1053-1056.

Li, H.M., Wang, J.D., 1989. Magnetostratigraphy of Permo-Triassic boundary section of Meishan of Changxing, Zhejiang. Sci. China, B 6, 652-658.

Menning, M., 1995. A numerical time scale for the permian and triassic periods: an integrated time analysis. In: Scholle, P.A., Peryt, T.M., Ulmer-Scholle, D.S. (Eds.), The Permian of Northern Pangea vol. 1, 77-97.

Menning, M., Gast, R., Hagdorn, H., Käding, K.C., Szurlies, M., Nitsch, E., 2005. Die Zeitskala für die höhere Dyas und die Germanische Trias der Stratigraphischen Tabelle von Deutschland 2002. Newsl. Stratigr. 41, 173-210.

Mørk, A., Elvebakk, E., Forsberg, A.W., Hounslow, M.W., Nakrem, H.A., Vigran, J.O., Weitschat, W., 1999. The type section of the Vikinghøgda Formation: a new Lower Triassic unit in central and eastern Svalbard. Polar Res. 18, 51-82.

Mundil, R., Ludwig, K.R., Metcalfe, I., Renne, P.R., 2004. Age and Timing of the Permian Mass Extinctions: U/Pb Dating of ClosedSystem Zircons. Science 305, 1760-1763.

Muttoni, G., Kent, D.V., Meço, S., Nicora, A., Gaetani, M., Balini, M., Germani, D., Rettori, R., 1996. Magnetobiostratigraphy of the Spathian to Anisian (Lower to Middle Triassic) Kçira section, Albania. Geophys. J. Int. 127, 503-514.

Nawrocki, J., 1997. Permian to Early Triassic magnetostratigraphy from the Central European Basin in Poland: implications on regional and worldwide correlations. Earth Planet. Sci. Lett. 152, 37-58.

Nawrocki, J., Szulc, J., 2000. The Middle Triassic magnetostratigraphy from the Peri-Tethys basin in Poland. Earth Planet. Sci. Lett. $182,77-92$.

Ogg, J.G., Steiner, M.B., 1991. Early Triassic magnetic polarity time scale - integration of magnetostratigraphy, ammonite zonation and sequence stratigraphy from stratotype sections (Canadian Arctic Archipelago). Earth Planet. Sci. Lett. 107, 69-89.
Ovtcharova, M., Bucher, H., Schaltegger, U., Galfetti, T., Brayard, A., Guex, J., 2006. New Early to Middle Triassic U-Pb ages from South China: Calibration with ammonoid biochronozones and implications for the timing of the Triassic biotic recovery. Earth Planet. Sci. Lett. 243, 463-475.

Paul, J., Klarr, K., 1988. Feinstratigraphie und Fazies des Unteren und Mittleren Buntsandsteins in der Bohrung Remlingen 5. GSF-Bericht 8/87. 148 pp.

Rampino, M.R., Prokoph, A., Adler, A., 2000. Tempo of the endPermian event: high-resolution cyclostratigraphy at the PermianTriassic boundary. Geology 28, 643-646.

Retallack, G.J., 1995. Permian-Triassic life crisis on land. Science 267, 77-80.

Röhling, H.G., Stollhofen, H., Tietze, K.W., 2002. Trias-Exkursion I. Buntsandstein zwischen Hannover und Würzburg. In: Niebuhr, B. (Ed.), Geo2002 - Planet Erde: Vergangenheit, Entwicklung. Zukunft, Schriftenreihe Dt. Geol. Ges., vol. 22, pp. 5-28.

Roman, A., 2004. Sequenzstratigraphie und Fazies des Unteren und Mittleren Buntsandsteins im östlichen Teil des Germanischen Beckens (Deutschland, Polen), $\mathrm{PhD}$ thesis Univ. Halle, 144 pp.

Scholger, R., Mauritsch, H.J., Brandner, R., 2000. Permian-Triassic boundary magnetostratigraphy from the Southern Alps (Italy). Earth Planet. Sci. Lett. 176, 495-508.

Soffel, H.C., Wippern, J., 1998. Magnetostratigraphy of Upper Permian and Lower Triassic Rocks from the drill site Obernsees near Bayreuth, Germany. Geol. Bavarica 103, 275-294.

Steiner, M., Ogg, J., Zhang, Z., Sun, S., 1989. Late Triassic magnetic polarity time scale and plate motions of south China. J. Geophys. Res. 94, 7343-7363.

Szurlies, M., 2001. Zyklische Stratigraphie und Magnetostratigraphie des Unteren Buntsandsteins in Mitteldeutschland, PhD thesis Univ. Halle, 116 pp.

Szurlies, M., 2004. Magnetostratigraphy: the key to a global correlation of the classic Germanic Trias - case study Volpriehausen Formation (Middle Buntsandstein), Central Germany. Earth Planet. Sci. Lett. 227, 395-410.

Szurlies, M., 2005. Zyklostratigraphische Kalibrierung 2005, Buntsandstein. In: Menning, M., Gast, R., Hagdorn, H., Käding, K.-C., Simon, T., Szurlies, M., Nitsch, E. (Eds.), Zeitskala für Perm und Trias in der Stratigraphischen Tabelle von Deutschland 2002, zyklostratigraphische Kalibrierung der höheren Dyas und Germanischen Trias und das Alter der Stufen Roadium bis Rhaetium 2005. Newsl. Stratigr., vol. 43, pp. 173-210.

Szurlies, M., Kozur, H.W., 2004. Preliminary paleomagnetic results from the Permian-Triassic boundary interval, Central and NW Iran. Albertiana 31, 41-46.

Szurlies, M., Bachmann, G.H., Menning, M., Nowaczyk, N.R., Käding, K.C., 2003. Magnetostratigraphy and high-resolution lithostratigraphy of the Permian-Triassic boundary interval in Central Germany. Earth Planet. Sci. Lett. 212, 263-278.

Tong, J., Zakharov, Y.D., Orchard, M.J., Yin, H., Hansen, H.J., 2004 Proposal of Chaohu Section as the GSSP Candidate of the InduanOlenekian Boundary. Albertiana 29, 13-28.

Twitchett, R.J., Looy, C.V., Morante, R., Visscher, H., Wignall, P.B., 2001. Rapid and synchronous collapse of marine and terrestrial ecosystems during the end-Permian biotic crisis. Geology 29, $351-354$.

Van der Voo, R., Torsvik, T.H., 2004. The quality of the European Permo-Triassic Paleopoles and its impact on Pangea reconstructions. In: Channell, J.E.T., Kent, D.V., Lowrie, W., Meert, J.G. (Eds.), Timescales of the Paleomagnetic Field. Geophys. Monograph, vol. 145 , pp. $29-42$. 
Visscher, H., Brugman, W.A., Van Houte, M., 1993. Chronostratigraphical and sequence stratigraphic interpretation of the palynomorph record from the Muschelkalk of the Obernsees well, south Germany. In: Hagdorn, H., Seilacher, A. (Eds.), Muschelkalk, Schöntaler Symposium 1991. Sonderb. Ges. Narturk. Württemberg, vol. 2, pp. 145-152.

von Alberti, F., 1834. Beitrag zu einer Monographie des Bunten Sandsteins, Muschelkalks und Keupers, und die Verbindung dieser Gebilde zu einer Formation. Cotta. 366 pp.

Ward, P.D., Botha, J., Buick, R., De Kock, M.O., Erwin, D.H., Garrison, G.H., Kirschvink, J.L., Smith, R., 2005. Abrupt and gradual extinction among Late Permian land vertebrates in the Karoo Basin, South Africa. Science 307, 709-714.
Wignall, P.B., Morante, R., Newton, R., 1998. The Permo-Triassic transition in Spitsbergen: $\delta 13 \mathrm{C}_{\text {org }}$ chemostratigraphy, Fe and $\mathrm{S}$ geochemistry, facies, fauna and trace fossils. Geol. Mag. 135, 47-62.

Yin, H., Feng, Q., Lai, X., Baud, A., Tong, J., 2006. The protracted Permo-Triassic crisis and multi-episode extinction around the Permian-Triassic boundary. Global Planet. Change 55, 1-20.

Zhu, Y., Liu, Y., 1999. Magnetostratigraphy of the Permo-Triassic boundary section at Meishan, Changxing, Zhejiang Province. In: Yin, H., Tong, J. (Eds.), Proceedings of the International Conference on Pangaea and the Paleozoic-Mesozoic transition. China Univ. Geosci. Press, pp. 79-84. 